Review

\title{
To Feed or not to Feed? Evidence of the Intended and Unintended Effects of Feeding Wild Ungulates
}

\author{
JOS M. MILNER, ${ }^{1}$ Department of Forestry and Wildlife Management, Hedmark University College, Campus Evenstad NO-2480 Koppang, Norway; \\ and School of Biological Sciences, University of Aberdeen, Tillydrone Avenue, Aberdeen AB24 2TZ, UK \\ FLORIS M. VAN BEEST, Department of Bioscience, Aarbus University, Frederiksborgvej 399, Roskilde 4000, Denmark \\ KAROLINE T. SCHMIDT, Dr. Moritz Zandergasse 7, 2380 Perchtoldsdorf, Austria \\ RYAN K. BROOK, Department of Animal and Poultry Science $\mathbb{E}$ Indigenous Land Management Institute, College of Agriculture and Bioresources, \\ University of Saskatchewan, 51 Campus Drive, Saskatoon SK S7N 5E2, Canada \\ TORSTEIN STORAAS, Department of Forestry and Wildlife Management, Hedmark University College, Campus Evenstad NO-2480 Koppang, \\ Norway
}

\begin{abstract}
Ungulate populations are important natural resources, associated with both costs and benefits. Conflicts have arisen between stakeholders who benefit from high ungulate numbers and those faced with the costs. Supplementary or diversionary feeding may potentially mitigate conflicts while maintaining harvest yields but can have conservation implications. We quantified the empirical evidence for whether the intended effects, and hence management goals, of feeding are met. We also examined whether any potential unintended consequences of feeding occur and under what conditions. We found clear evidence that supplementary feeding enhanced reproduction and population growth under certain conditions. By contrast, we found limited evidence of the effectiveness of diversionary feeding to protect crops, forestry, and natural habitats, with positive effects often undermined by increases in ungulate density. However, the use of diversionary feeding to reduce traffic collisions seems promising but requires further investigation. The unintended effects of feeding are typically complex, involving changes to demography, behavior, and vegetation with consequent cascading effects on other trophic levels, as well as exacerbated risks of disease transmission. Increased ungulate density is the primary driver behind these unintended effects, the consequences of which tend to increase with longevity of feeding and affect a range of stakeholders. We urge managers to take seriously the risks as well as the economic and ethical issues before deciding to feed ungulates. (C) 2014 The Wildlife Society.
\end{abstract}

KEY WORDS artificial feeding, deer, forest damage, habitat impact, herbivore, hunting, supplemental feed, sustainable management, vehicle collision, wildlife disease.

Large ungulates are keystone species in many ecosystems and are a highly valued natural resource for social, cultural, and economic reasons (Gordon et al. 2004). Many populations have grown over recent decades, causing environmental and socio-economic impacts on wider communities and conservation concerns, as well as density-dependent changes in performance (Côté et al. 2004, Putman et al. 2011). Consequently, conflicts arise between stakeholders who benefit economically from high ungulate numbers (e.g., hunters, outfitters, tourism operators) and those faced with the costs of their presence (e.g., land managers, conservationists, transport users, and operators; Austin et al. 2010). Manipulating forage availability through the provision of additional food could potentially be a means of mitigating this conflict while

Received: 4 March 2014; Accepted: 12 August 2014

${ }^{1}$ E-mail: jos.milner@gmail.com maintaining hunter harvest yields and hence rural incomes (Brown and Mandery 1962, Smith 2001). However, some stakeholders have concerns over the sustainability of this management practice and its potentially undesirable ecological side effects (Mysterud 2010, Martínez-Abraín and Oro 2013).

Wildlife can be fed by humans in many different ways, intentionally (e.g., at feeding stations) and unintentionally (e.g., unprotected agricultural crops and rubbish dumps; Oro et al. 2013, Sorensen et al. 2014). In this review, we focus on the effects of intentional feeding of ungulates, specifically considering supplementary feeding (often called winter feeding) and diversionary, or intercept, feeding used to attract animals away from vulnerable vegetation, livestock, or major traffic arteries (defined fully in Supplemental Material). However, many of the issues raised also apply across a broad range of unintentional but predictable anthropogenic food subsidies (Oro et al. 2013). Earlier reviews of the consequences of feeding large herbivores, published a decade or more ago, found equivocal evidence of 
its effectiveness (Peek et al. 2002, Putman and Staines 2004). Since then both the scale and extent of feeding have increased (Tarr and Pekins 2002, Bartoskewitz et al. 2003, Mysterud 2010), along with a greater awareness and research focus on its unintended consequences (Inslerman et al. 2006). We therefore summarize the findings of ungulate feeding studies with the aim of establishing 1) the effectiveness of feeding programs, 2) the conditions under which management goals are likely to be achieved, and 3) the conditions under which unintended effects are most likely to occur.

\section{METHODS}

We reviewed articles in the peer-reviewed and, to a lesser extent, gray literature that provided empirical evidence of the effects of feeding ungulates throughout the world. We used ISI Web of Knowledge and Google Scholar to identify articles. The search terms, using Web of Knowledge syntax, were (supplement* OR diversion OR intercept OR artificial) AND (feed* OR forag*) and we refined results by (bison OR boar OR deer OR elk OR moose OR ungulate). We manually excluded studies of farmed populations of ungulates. Adding relevant papers and reports cited in key articles but not picked up by our search terms resulted in 232 articles.

We identified 5 major management goals of supplementary and diversionary feeding and considered the intended effects of feeding that would allow these goals to be achieved (Table 1). We also identified commonly perceived unintended or secondary consequences of feeding (Table 2). We quantified the evidence for the occurrence of intended and unintended effects and collated information on the conditions under which they occurred. In our analysis of the evidence, we included only controlled studies in which there was variation in the amount of feed provided over time or space, or in which comparisons were made between treatment (fed) and control (unfed) groups, or before and after feeding started or ended $(n=101)$. These studies came from North America (48 studies), Fennoscandia (25), or elsewhere in Europe (28) and focused on 9 different ungulate species (Supplemental Material Fig. S1, Tables S1-S4). As the implementation of feeding programs likely influences their outcome, we recorded the type of feed provided (i.e., concentrates: fruits, root crops, grain, maize (corn), or pelleted concentrates; bulk feeds: pelleted or unprocessed bulk forage crops including silage, hay, and other roughage) and feed distribution method (feeder units [e.g., hoppers, gravity feeders, troughs], bales of bulk crops, piles of feed or bait, feed spread on ground in lines or scattered) where this information was given (Supplemental Material Fig. S1). We also recorded how long the program had been running. Other factors such as the length of the feeding season, the proportion of the population using supplementation, the quantity of feed provided, and the density or spatial distribution of feeding stations are also likely to be important but were often not reported.

We examined whether or not there was evidence of an effect of feeding using logistic regression, assuming a binomial distribution (0: no evidence or evidence in the opposite direction to intended or predicted; 1 : evidence in the intended or predicted direction). Explanatory variables were the effect type (intended or unintended), management type (supplementary or diversionary feeding), feed type and distribution method (both classified above), feeding program history (short: $<5$ years; medium: 5-20 years; long: $>20$ years), and their interactions.

\section{RESULTS}

We found stronger evidence of the intended effects of supplementary than diversionary feeding (supporting evidence found in $63.4 \%$ and $34.4 \%$ of studies, respectively; $\left.\chi_{1,101}^{2}=7.54 ; P=0.006\right)$. Furthermore, evidence supported the occurrence of unintended effects more often than intended effects $\left(\chi_{1,168}^{2}=7.29 ; P=0.007\right)$ and among unintended effects, the probability of occurrence increased with duration of the feeding program $\left(\chi_{2,50}^{2}=6.19\right.$; $P=0.045)$. An effect of fewer unintended effects when feeding concentrates $\left(\chi_{2,61}^{2}=9.71 ; P=0.008\right)$ arose because concentrates were often associated with short-term feeding programs (Supplemental Material Fig. S1). Otherwise, we found no significant effects of feed type, distribution method, or program duration, but this may be partly because of low sample sizes or the disproportionate representation of some study systems.

\section{Effectiveness in Meeting Management Goals}

Improved performance.-Ecological theory suggests that an increase in the availability of food resources would lead to improved body condition and consequently increased survival and reproductive rates (Bayliss and Choquenot 2002). Indeed these are the intended effects of many supplementary feeding programs (Table 1). Despite this, Putman and Staines (2004) reported relatively little effect of feeding on demographic factors in deer. In contrast, by restricting our evidence to that of case-controlled studies, we found stronger evidence of increased performance under certain conditions (Table 1). A high population density relative to nutritional carrying capacity is one such condition, with performance gains being more likely when supplementary feed is provided to a population with poor natural forage resources (Tarr and Pekins 2002, Bartoskewitz et al. 2003).

Performance gains are less likely to be detected if there is a mismatch between the season in which feed is provided and the season in which demographic parameters are measured. We found evidence that feeding during winter reduced natural overwinter mass loss or loss of condition in $5 / 7$ studies (Table 1), with enhanced body reserves likely providing an insurance against extreme winter conditions (Fauchald et al. 2004, Bårdsen et al. 2008). By contrast, no studies $(n=7)$ showed a clear effect of winter feeding on carcass weights the following autumn or hunting season (Table 1). Autumn mass is generally more dependent on the quality of summer foraging conditions that replenish body reserves after winter, than on conditions during the previous winter (Parker et al. 2009, Cook et al. 2013). However, where animals are provisioned year-round (typically in 
Table 1. Intended effects associated with the main management goals of ungulate feeding and the number of empirical studies providing evidence in support of each per the number of relevant studies. We also provide conditions under which intended effects are most likely to occur. Full details of all evidence are provided in Supplemental Material (Tables S1 and S2).

\begin{tabular}{|c|c|c|c|c|}
\hline Type of feeding & Management goal & Intended effect & Evidence & Conditions \\
\hline \multirow[t]{12}{*}{ Supplementary feeding } & $\begin{array}{l}\text { Improved individual or } \\
\text { population performance }\end{array}$ & Increased survival rate & $4 / 7$ & $\begin{array}{l}\text { Low natural survival rates; food-limited } \\
\text { populations; severe weather years; fed for } \\
\text { entire winter; areas of low disturbance; } \\
\text { vulnerable age and sex classes benefit } \\
\text { most }\end{array}$ \\
\hline & & $\begin{array}{l}\text { Increased reproductive } \\
\text { rate }\end{array}$ & $5 / 8$ & $\begin{array}{l}\text { Low natural reproductive rates; popula- } \\
\text { tions close to carrying capacity; summer } \\
\text { forage not limiting; sufficient proportion } \\
\text { of females fed to give population-level } \\
\text { response }\end{array}$ \\
\hline & & Increased birth mass & $1 / 3$ & $\begin{array}{l}\text { Low environmental stochasticity; small } \\
\text { mothers benefit most }\end{array}$ \\
\hline & & $\begin{array}{l}\text { Reduced winter mass loss } \\
\text { or improved winter con- } \\
\text { dition }\end{array}$ & $5 / 7$ & $\begin{array}{l}\text { Winter forage-limited populations; nat- } \\
\text { ural adaptations to winter not compro- } \\
\text { mised (e.g., feeding stations not in } \\
\text { thermally unfavorable areas); areas of low } \\
\text { human disturbance }\end{array}$ \\
\hline & & $\begin{array}{l}\text { Increased autumn mass or } \\
\text { condition }\end{array}$ & $3 / 11$ & $\begin{array}{l}\text { Generally only where supplement pro- } \\
\text { vided year round or during summer or } \\
\text { autumn; exception may be among year- } \\
\text { lings }\end{array}$ \\
\hline & & $\begin{array}{l}\text { Increased offspring au- } \\
\text { tumn mass or condition }\end{array}$ & $4 / 6$ & $\begin{array}{l}\text { Low environmental stochasticity; heavier } \\
\text { females benefit most; where additional } \\
\text { resources not invested in greater number } \\
\text { of offspring }\end{array}$ \\
\hline & & Increased antler growth & $2 / 5$ & $\begin{array}{l}\text { Natural mineral availability is restricted } \\
\text { and mineral supplement provided during } \\
\text { antler growing season }\end{array}$ \\
\hline & $\begin{array}{l}\text { Compensation for loss of } \\
\text { natural range }\end{array}$ & $\begin{array}{l}\text { Increased carrying capa- } \\
\text { city }\end{array}$ & $3 / 3$ & $\begin{array}{l}\text { Food-limited populations; adequate } \\
\text { water supply; summer forage conditions } \\
\text { not limiting }\end{array}$ \\
\hline & $\begin{array}{l}\text { Improved hunting or } \\
\text { viewing opportunities }\end{array}$ & $\begin{array}{l}\text { Increased population size } \\
\text { or density }\end{array}$ & $4 / 6$ & $\begin{array}{l}\text { Food-limited populations; harvesting is } \\
\text { not limiting }\end{array}$ \\
\hline & & $\begin{array}{l}\text { Increased aggregation or } \\
\text { group size }\end{array}$ & $2 / 2$ & $\begin{array}{l}\text { Feeding or baiting during hunting sea- } \\
\text { son; medium- to long-term feeding in } \\
\text { predictable locations }\end{array}$ \\
\hline & & $\begin{array}{l}\text { Concentration of activity } \\
\text { at feeding sites }\end{array}$ & $8 / 8$ & Feed sites within home range only \\
\hline & & Increased hunting success & $1 / 4$ & $\begin{array}{l}\text { Feeding or baiting during hunting sea- } \\
\text { son; greater increase in success among } \\
\text { archery hunters }\end{array}$ \\
\hline \multirow[t]{4}{*}{ Diversionary feeding } & $\begin{array}{l}\text { Reduced traffic collision } \\
\text { rate }\end{array}$ & $\begin{array}{l}\text { Diversion of animals from } \\
\text { traffic arteries }\end{array}$ & $1 / 3$ & $\begin{array}{l}\text { Feeding stations at end of migration } \\
\text { route or within wintering area }\end{array}$ \\
\hline & & $\begin{array}{l}\text { Restricted ranging (re- } \\
\text { duced home range size) }\end{array}$ & $3^{\mathrm{a} / 8}$ & $\begin{array}{l}\text { Not clear; food-limited populations most } \\
\text { likely }\end{array}$ \\
\hline & & $\begin{array}{l}\text { Controlled spatial distri- } \\
\text { bution (altered migration } \\
\text { patterns) }\end{array}$ & $3 / 5$ & $\begin{array}{l}\text { Not clear; most likely in areas of little } \\
\text { snow, within wintering areas and in } \\
\text { combination with fences }\end{array}$ \\
\hline & $\begin{array}{l}\text { Reduced crop, forest, or } \\
\text { habitat damage }\end{array}$ & $\begin{array}{l}\text { Diet changed from crops, } \\
\text { trees, or natural forage to } \\
\text { provided feed }\end{array}$ & $6^{\mathrm{b}} / 16$ & $\begin{array}{l}\text { Where population density is kept low; } \\
\text { feed type similar to natural forage; feed } \\
\text { sites not near vulnerable vegetation }\end{array}$ \\
\hline
\end{tabular}

${ }^{\text {a }}$ One study showed a significant response in the opposite direction to that intended.

${ }^{\mathrm{b}}$ Four studies showed a significant response in the opposite direction to that intended.

mediterranean climates [e.g., Texas and Spain]; Olguin et al. 2013) or winter supplementary feeding begins in autumn (Bartoskewitz et al. 2003), autumn weights may increase, particularly among yearlings and males (3/4 studies; Supplemental Material Table S1).

Among adult females, an effect of feeding is complicated by the strong impact of reproductive status on autumn mass (Cook et al. 2013). Where resources from winter feeding are largely allocated to reproduction rather than somatic growth (e.g., Bårdsen et al. 2008, Milner et al. 2013), greater energetic investment in lactation during the summer can lead to lower autumn mass among fed than unfed adult females with fewer or no offspring (Bårdsen et al. 2009, van Beest and Milner 2013). Consequently, offspring of supplementally fed females are often heavier (Table 1) because of increased milk yields and higher neonatal growth rates (Jacobsen et al. 1981, Smith et al. 1997).

The reproductive rate (number of offspring per adult female in summer or autumn) of supplementally fed herbivores increased in 5/7 studies (Table 1 ). In those 
Table 2. Evidence of the occurrence of unintended effects of feeding wild ungulates in terms of the number of empirical studies providing support per the number of relevant studies. Conditions under which risks of unintended effects are likely to be increased are also given. Full details of all supporting evidence are given in Supplemental Material (Table S3).

\begin{tabular}{|c|c|c|c|}
\hline Effect on & Unintended effect & Evidence & Conditions expected to promote risk \\
\hline \multirow[t]{2}{*}{ Population dynamics } & $\begin{array}{l}\text { Reduced population } \\
\text { fluctuations }\end{array}$ & $0 / 1$ & Not clear \\
\hline & $\begin{array}{l}\text { Increased population } \\
\text { growth rate and reduced } \\
\text { density dependence }\end{array}$ & $3 / 3$ & $\begin{array}{l}\text { Food-limited populations before new carrying capacity is } \\
\text { approached }\end{array}$ \\
\hline \multirow[t]{3}{*}{ Genetics and selection pressures } & $\begin{array}{l}\text { Changed spatial genetic } \\
\text { structure }\end{array}$ & $1 / 1$ & $\begin{array}{l}\text { Where aggregation of multiple kin-structured social } \\
\text { groups (e.g., matrilines) occurs }\end{array}$ \\
\hline & Reduced natural selection & $1 / 1$ & $\begin{array}{l}\text { Sufficient feeding to reduce winter mortality but } \\
\text { distribution method limits access of subordinates }\end{array}$ \\
\hline & $\begin{array}{l}\text { Increased variance in male } \\
\text { mating success affecting } \\
\text { sexual selection }\end{array}$ & $1 / 1$ & $\begin{array}{l}\text { Feeding during rut; polygynous mating systems; } \\
\text { aggregation of females; increased female harem size }\end{array}$ \\
\hline \multirow[t]{2}{*}{ Behavior } & Increased aggression & $4 / 5$ & $\begin{array}{l}\text { Restricted access to feed; feed distribution clumped; feed } \\
\text { quantity rationed; high animal density }\end{array}$ \\
\hline & Increased stress & $1 / 1$ & High density aggregations; high levels of aggression \\
\hline \multirow[t]{5}{*}{ Vegetation and habitats } & $\begin{array}{l}\text { Increased local browsing } \\
\text { or grazing }\end{array}$ & $4 / 4$ & $\begin{array}{l}\text { Long-term feeding; sustained heavy browsing or grazing; } \\
\text { feed distribution clumped }\end{array}$ \\
\hline & $\begin{array}{l}\text { Increased selective fora- } \\
\text { ging or impact on pre- } \\
\text { ferred species }\end{array}$ & $2 / 4$ & $\begin{array}{l}\text { Not clear; may be interannual and seasonal effects; may } \\
\text { depend on availability and palatability of alternative } \\
\text { forage }\end{array}$ \\
\hline & $\begin{array}{l}\text { Changed plant species } \\
\text { composition }\end{array}$ & $3 / 3$ & Long-term feeding; sustained heavy browsing or grazing \\
\hline & $\begin{array}{l}\text { Decline in shrubs and } \\
\text { woody vegetation or cover }\end{array}$ & $4 / 4$ & Long-term feeding; sustained heavy browsing or grazing \\
\hline & $\begin{array}{l}\text { Invasion of non-native } \\
\text { weed species }\end{array}$ & $2 / 3$ & Non-local feed; contaminated feed \\
\hline \multirow[t]{2}{*}{ Other taxa } & $\begin{array}{l}\text { Negative effect on } \\
\text { biodiversity }\end{array}$ & $1 / 3$ & $\begin{array}{l}\text { Sustained heavy browsing or grazing; reduction in } \\
\text { habitat or niche heterogeneity; species replacement does } \\
\text { not occur }\end{array}$ \\
\hline & $\begin{array}{l}\text { Impact on non-target } \\
\text { species }\end{array}$ & $6 / 7$ & $\begin{array}{l}\text { Large scale, long-term feeding; increased nest predation } \\
\text { most likely when feeding during nesting season }\end{array}$ \\
\hline \multirow[t]{4}{*}{ Parasite and disease risk } & $\begin{array}{l}\text { Increased parasitism due } \\
\text { to spatial aggregation and } \\
\text { increased contact rates }\end{array}$ & $10 / 14$ & $\begin{array}{l}\text { Diseases with density dependent transmission; parasites } \\
\text { with direct life cycle; season of transmission coincides } \\
\text { with feeding season; feeding within geographic range of } \\
\text { infectious disease; few or aggregated feeders; feed } \\
\text { delivery facilitates nose-to-nose contact; high pathogen } \\
\text { survival in environment; long feeding season }\end{array}$ \\
\hline & $\begin{array}{l}\text { Reduced parasitism due to } \\
\text { improved body condition }\end{array}$ & $2 / 4$ & $\begin{array}{l}\text { Diseases inducing high immunity; food-limited popula- } \\
\text { tions }\end{array}$ \\
\hline & $\begin{array}{l}\text { Feed acts as an effective } \\
\text { disease fomite }\end{array}$ & $2 / 2$ & Feed supports diseases in environment \\
\hline & Rumen overload & $1 / 4$ & Not clear \\
\hline
\end{tabular}

studies showing clear positive effects, population density was generally high or increasing relative to the natural forage availability (e.g., Milner et al. 2013). Under such circumstances, feeding can provide a buffer against the adverse effects of density and environmental stochasticity on the life-history traits of adult females (Rodriguez-Hidalgo et al. 2010, Ballesteros et al. 2013). Where reproductive rate is already naturally high, feeding is not likely to increase it further (e.g., 92\% calving in semi-domesticated reindeer; Fauchald et al. 2004).

The effects of feeding on survival tend to be weak, particularly in adults, which have naturally high overwinter survival. Improved survival occurs primarily among juveniles (Ozoga and Verme 1982, Smith and Anderson 1998) and in severe winters (Lewis and Rongstad 1998, Tarr and Pekins 2002, Fauchald et al. 2004), particularly where individuals congregate on degraded winter ranges (Peterson and Messmer 2007). In heavily hunted populations where density is kept below habitat carrying capacity, natural winter mortality tends to be low, thus constraining any survival benefit of feeding (Lewis and Rongstad 1998). Ultimately the effectiveness of feeding programs to improve performance at the population level depends on the proportion of individuals using the feed (Bartoskewitz et al. 2003). For example, a low proportion of female white-tailed deer (Odocoileus virginianus) used supplementary summer feed in a study in Texas that showed no significant effect of feeding on female body mass, whereas a high proportion of males used the feed resulting in significant effects on antler size and mass of some age classes (Bartoskewitz et al. 2003).

Compensation for loss of range.-Although many feeding programs, particularly in North America, state compensation for loss or fragmentation of natural winter range as their rationale (Smith 2001, Peterson and Messmer 2011), few controlled studies $(n=3)$ reported the effects of feeding on carrying capacity (Supplemental Material Table S1). At the population level, we would expect that feeding increases nutritional carrying capacity and therefore population 
density, if other factors are not limiting (Brown and Cooper 2006, Oro et al. 2013). This reduces the effects of density dependence (Lubow and Smith 2004), and population growth rates may increase (e.g., Ballesteros et al. 2013) until a new higher carrying capacity is approached (Ozoga and Verme 1982). Although our findings supported this pattern (Table 1), feeding programs also have the potential to decrease carrying capacity at high densities, either through negative impacts on summer or autumn forage availability (Ozoga and Verme 1982) or through an increase in yearround use of limited winter ranges because of changes in migration patterns (Peterson and Messmer 2011).

Increased bunting and viewing opportunities.-Feeding is expected to increase hunting and game viewing opportunities either as a result of higher hunting quotas based on larger ungulate population sizes or through increased encounter rates. The latter may result from either an increase in population size or density, or through changes in spatial behavior that increase aggregation or spatial predictability of game species. The latter underlies the practice of baiting by hunters (van Deelen et al. 2006) and can keep game within a desired hunting ground, eventually disrupting the tradition of migration under long-term feeding (Peek et al. 2002).

As indicated above, population density often increases as a result of feeding (evidence from $4 / 6$ studies; Table 1 ). We also found strong evidence that the provision of additional forage at focal points in the landscape alters the distribution and natural foraging behavior of animals, leading to increased local densities and aggregations around feeding stations (Table 1). Indeed, 8/8 studies observed a shift in activity center or core area within the home range towards feeding stations (e.g., Cooper et al. 2006, Webb et al. 2008), and a further 2 studies showed increased local density and group size (Sánchez-Prieto et al. 2004, Pérez-González et al. 2010).

Despite these intended effects being met, the evidence that they led to higher hunter success was weak (Table 1). Although a number of North American studies have reported increased hunting success of fed or baited white-tailed deer (see Dunkley and Cattet 2003, Inslerman et al. 2006), the differences in harvest rates between hunters using and not using bait were often small and not tested statistically (e.g., Winterstein 1992). Of 4 controlled studies, 1 showed a significant improvement in hunting success (Table 1; Supplemental Material Table S1). Baiting was most effective among archery hunters who require closer proximity to the animal for success (van Deelen et al. 2006, Kilpatrick et al. 2010). Other studies suggested that baiting neither improved hunter success nor increased landscape-level deer harvests (van Deelen et al. 2006, Tardiff Fleegle and Rosenberry 2010), although where a baiting ban reduces hunter numbers, the total harvest may decrease (Rudolph et al. 2006).

Reduced vehicle collisions. - The use of diversionary feeding to reduce collisions is based on an expected alteration of the movement and spatial distribution of animals. For example, animals may be intercepted during migration or their movement and ranging behavior restricted. However, evidence that feeding alters migratory behavior of ungulates was equivocal (3/5 studies; Table 1$)$. Winter-feeding in Scandinavia was unable to halt moose (Alces alces) migration early in the migration phase (Sahlsten et al. 2010), although feeding stations close to the end of migration routes and within wintering areas were used (Gundersen et al. 2004, Sahlsten et al. 2010). This contrasts with the disruption of migration under long-term feeding in red deer (Cervus elaphus) on hunting grounds (Peek et al. 2002). Where feeding does not alter migration, spatial and seasonal variation in nutritional carrying capacity and predation risk seem to be more important determinants of migratory behavior (Mysterud 1999, White et al. 2010).

Evidence of restricted ranging was even weaker with $3 / 8$ studies showing that feeding reduced total home range size (Table 1), whereas other cases showed increased or unchanged home range size after the initiation of feeding (Supplemental Material Table S2). This is presumably due to the need to meet other resource requirements (Brown and Cooper 2006). For example, the use of cover to mediate unfavorable weather conditions or reduce predation risk also strongly influences spatiotemporal behavior (Merrill et al. 2010, van Beest and Milner 2013).

When habitat requirements other than forage are limiting around feeding stations, animals may actually increase their movement and adjust their space use or habitat selection to meet those needs (Webb et al. 2008). Although movement rates of white-tailed deer and Angora goats (Capra hircus) did not change after being offered supplemental feed (Murden and Risenhoover 1993), moose using feeding stations moved more than non-users (Mathisen et al. 2014) and fed mule deer (Odocoileus hemionus) moved farther from bed sites to feed (Peterson and Messmer 2011). In Alpine areas, red deer that were fed in thermally unfavorable valley bottoms for practical reasons, moved daily to the better thermal conditions of high elevation meadows, whereas nonsupplemented herds remained in alpine meadows throughout winter (Schmidt 1993). Nonetheless, although supplementary feeding does influence the distribution and habitat selection process of individuals, its effects appear to be largely restricted to small spatial and temporal scales (PérezGonzález et al. 2010, van Beest et al. 2010b).

Evaluations of mitigation efforts to reduce animal-vehicle collisions are widespread in the literature (e.g., Groot Bruinderink and Hazebroek 1996, Huijser et al. 2009), but few case studies have explicitly considered diversionary feeding (Table 1). There were 3 exceptions. In an area of high mule deer vehicle collisions, mortality due to collisions was similar in fed and unfed sites but was offset by increased productivity at the fed site (Peterson and Messmer 2011). Wood and Wolfe (1988) showed that feeding mule deer reduced vehicle collisions sufficiently to be economically beneficial although reductions were only significant in $2 / 6$ trials. Andreassen et al. (2005) found that 3 mitigation measures combined (forest clearing, feeding, predator scent) reduced moose-train collisions by $46 \%$. Both of the latter studies recommended further investigations into the effectiveness of diversionary feeding to reduce collisions, but none has occurred to date. 
Reduced damage to crops, forestry, and natural vegetation.Diversionary feeding may be used as a tool to reduce or prevent herbivore impacts on vegetation or habitats of high commercial or conservation value, either by altering the distribution of ungulates across the landscape or by altering their diet or habitat selection patterns. The effectiveness of feeding in controlling spatial distribution is described above and was found to be unclear. In terms of changing diet, we would intuitively expect that providing herbivores with additional forage should decrease their reliance on natural vegetation and reduce impacts on the environment (Schmitz 1990, Kowalczyk et al. 2011). However, empirical evidence shows that many supplementally fed herbivores continue to forage on natural vegetation, some without notable changes in their natural diet (e.g., Schmitz 1990, Doenier et al. 1997, Cooper et al. 2006, van Beest et al. 2010a). The only study to consider whether diversionary feeding altered habitat use found no difference between feeding site users and non-users (van Beest et al. 2010b).

Of 16 controlled studies, 6 showed diversionary feeding to be effective in reducing damage in the targeted areas, whereas 4 showed a significantly increased impact, opposing the management goal (Table 2). Efficacy was related to the type of feed provided, the proximity of feeding sites to vulnerable vegetation, the longevity of the feeding program, and its effects on population density. Nonetheless, managers may perceive diversionary feeding to be effective where there are economic benefits, regardless of the ecological outcome. For example, the reduction in damage to French vineyards by wild boar (Sus scrofa) as a result of diversionary feeding was sufficient for savings in compensation payments to be made, despite a statistically non-significant reduction in damage (Calenge et al. 2004).

Feed type in relation to the grazing or browsing strategy of the target species along the continuum from bulk roughage feeders to concentrate selectors, seems to influence effectiveness (Table 1). For example, providing silage and hay successfully reduced agricultural damage and browsing in European bison (Bison bonasus), a bulk feeder (Kowalczyk et al. 2011), but did not reduce forest damage by moose, a concentrate selector (van Beest et al. 2010a, Mathisen et al. 2014). Forestry residues are potentially a more effective feed type for reducing moose forest damage but have yet to be formally tested (Månsson et al. 2010). Low-fiber concentrates fed to mixed feeders such as elk (Cervus canadensis) and red deer increased the utilization of winter pasture (Kozak et al. 1994) and may reduce bark damage (Rajský et al. 2008), whereas high-fiber bulk diets reduced grazing pressure (Kozak et al. 1994). Concentrates fed to white-tailed deer (concentrate selectors) increased the proportion of natural browse in the diet in spring and forbs in autumn but had no effect on forage choices in summer or winter (Timmons et al. 2010). Natural forage may be required to balance a shortage of essential nutrients in the supplemental feed (Schmitz 1990), or stimulate the digestive tract to alleviate the risk of ruminal acidosis (Timmons et al. 2010).

More generally, feeding may exacerbate the scale of vegetation damage by contributing to ungulate population growth so increasing density and undermining any potential diversionary benefits. This is especially true for species with a high reproductive capacity such as wild boar (Bieber and Ruf 2005, Imesch-Bebié et al. 2010), and has been observed where long-term feeding ( $>20$ years) was associated with a high landscape-scale browsing impact as moose population density increased relative to natural forage availability (Mathisen et al. 2014).

\section{Evidence of Unintended Effects of Feeding}

Altered population dynamics. - Besides the intended demographic effects of feeding, there may be unintended demographic and evolutionary effects but in general these have been less well studied (Table 2). For example, density dependence may be reduced (Lubow and Smith 2004) with consequences for population dynamics. Consequently, we expected that feeding would lead to a reduction in variance in population size. However, we found no studies that formally addressed this (Table 2), although Boyce (1989) noted that fluctuations in the size of the Jackson elk herd were lessened, reducing the dynamic nature of the ecosystem.

Genetic effects and changes to selection. - Feeding may affect the genetic structure of populations. Spatial homogeneity of allele frequencies was increased in supplmentally fed whitetailed deer with the loss of microgeographic genetic structure normally associated with kin-structured social groups (Blanchong et al. 2006). Feeding may also reduce selection pressures on nutrition-mediated traits such as overwinter mortality (Schmidt and Hoi 2002) and reproductive success (Rodriguez-Hidalgo et al. 2010) by buffering individuals against the effects of environmental variation. Some overwinter mortality may be considered beneficial because it maintains natural selection against poor quality individuals (Boyce 1989). Supplementally fed red deer calves and yearlings showed higher intra-cohort variation and lower inter-cohort variation in body weight than among nonsupplemented red deer, implying that fed individuals may be under reduced natural selection pressure during their first year of life (Schmidt and Hoi 2002). However, there are no studies that explicitly examine the effects of feeding on natural selection, the evidence from red deer being circumstantial and likely distorted by selective hunting (Mysterud 2011).

Feeding may also affect sexual selection by increasing the variance in male mating success among polygynous species. Sánchez-Prieto et al. (2004) showed that spatially clumped feeding led to high aggregation of females and greater variance in harem sizes of red deer. This shows that feeding during the rut can increase the degree of polygyny, but no studies have explicitly measured male reproductive success in relation to feeding (Table 2).

Altered behavior.-Providing additional forage at focal points in the landscape clearly affects the spatial behavior of animals (Table 1). The concentrated activity and movement of animals around feeding stations described above match the predictions of central-place foraging theory (van Beest et al. 2010b). Such aggregation has consequences for social behavior, as well as inter- and intra-specific interactions and 
stress levels. Aggression (Donohue et al. 2013) and stress (Forristal et al. 2012) both increase with ungulate density, and 4/5 studies observed higher levels of aggression associated with feeding (e.g., Pérez-González et al. 2010).

Aggressive interactions and access of subordinates to supplemental feed vary seasonally (Ozoga and Verme 1982) and particularly with the way in which feeding is implemented in terms of feed type and its temporal and spatial distribution (Schmidt et al. 1998, Schmidt and Hoi 1999). Interference competition generally increases with increasing spatial clumping of resources. For example, a clumped feed distribution provided to red deer during the rut led to higher rates of male-male interaction and male harassment of females than a dispersed feed distribution, although females experienced lower per capita harassment because of larger harem sizes (Sánchez-Prieto et al. 2004). Nonetheless, aggressive interactions are not always sufficient to result in interference competition (Veiberg et al. 2004). Patch size, profitability and depletion rate influence the extent of interference competition and aggression, particularly among subordinate males, which may avoid using feeding sites if patch profitability is too low for efficient participation (Schmidt et al. 1998). Interspecific spatial avoidance may also occur, as observed where moose and red deer used feeding stations in the same areas (Johnsen 2012).

Impacts on vegetation and habitats.-Where vegetation is not protected by snow in winter, patterns of habitat or range degradation associated with ungulate feeding can be similar to those observed around artificial water holes used by domestic livestock (Andrew 1988). Habitat impacts include changes in plant composition and diversity due to increased browsing pressure on woody dwarf shrubs (Mathisen et al. 2010) and trees (Smith et al. 2004), a consequent loss of understory cover (Pedersen et al. 2014), and an increase in light-demanding species and grasses (Mathisen et al. 2010). Evidence of all these effects has been documented (Table 2), but they occur primarily as consequences of an increase in local herbivore density rather than a direct consequence of feeding. Few studies tease these factors apart, with the input of nutrients being an important additional factor at feed sites (Mathisen and Skarpe 2011).

In studies addressing the increased probability of browsing or grazing impacts in response to feeding (4/4 studies; Table 2 and Supplemental Material Table S3), such effects were typically strongest in the immediate vicinity of feeding stations and weakened with increasing distance from feeding stations (van Beest et al. 2010a). Increased utilization (Peterson and Messmer 2011) or depletion (Cooper et al. 2006, van Beest et al. 2010a) of preferred natural forage species is commonly found in areas with feeding, with the extent being determined by feeding history, as well as the quantity and quality of the provided feed (Brown and Cooper 2006, Kowalczyk et al. 2011). Indeed, the area over which impact on the natural vegetation occurs can increase considerably with feeding program duration and may be sustained by re-browsing for a number of years after feeding stations cease operating (van Beest et al. 2010a). Nonetheless, landscape heterogeneity may allow the regeneration of preferred species despite close proximity to feeding sites and high herbivore densities, particularly in species such as aspen (Populus tremuloides) with episodic regeneration (Barnett and Stohlgren 2001).

Supplementary feeding of free-ranging ungulates is often practiced in natural habitats and as such poses a risk of introducing exotic weed species into native ecosystems (Rinella et al. 2012), which can be further dispersed by wind, birds, or mammals. Feed products such as hay bales, oilseeds, cereals, and pulse crops are generally contaminated with seeds of a variety of weed species. Even processed feeds such as pellets made from hay and grain may contain viable weed seeds (Cash et al. 1998). These seeds can sometimes survive for years or decades before germinating (Lewis 1973). Ungulates can disperse seeds of exotic and native species widely (Bartuszevige and Endress 2008), with viable weed seeds found in the feces from ruminants for days after consumption (Wallander et al. 1995, Jaroszewicz et al. 2009). Furthermore, colonization by exotic invasive plant species is facilitated by reduced competition from heavily browsed native vegetation (Rinella et al. 2012) and soil disturbance in areas of concentrated activity at feeding sites (MacDougall and Turkington 2005). Despite an increasing awareness of the role played by ungulates in spreading seeds (Bartuszevige and Endress 2008, Picard and Baltzinger 2012), we found only 2 documented cases, both from the Greater Yellowstone Ecosystem, USA, where the spread of invasive plant species was directly attributable to feeding (Table 2). A third study showed a slightly higher species diversity, proportion of synanthropic species, and number of seedlings per dung sample in supplementally fed than unfed groups of European bison, although differences were not significant (Jaroszewicz et al. 2009).

Impacts on other taxa.-Feeding has both direct and indirect effects across whole ecosystems by altering patterns of herbivory and nutrient input (Mathisen and Skarpe 2011). These factors alter the competitive balance between species and hence community composition, which in turn can have cascading effects through the trophic levels. Much research effort has focused on the negative impacts on biodiversity and species richness of sustained heavy grazing and browsing (Fuller and Gill 2001, Côté et al. 2004, Foster et al. 2014) without considering the potential balancing effects of nutrient input due to feeding (Mathisen and Skarpe 2011). Although feeding affected the composition of small mammal (Pedersen et al. 2014) and passerine bird (Anderson 2007, Mathisen and Skarpe 2011) communities, only 1 of these 3 studies reported a reduction in species richness (Table 2); shrub-steppe bird species were favored at the expense of woodland species (Anderson 2007). Overall biodiversity may be unaffected if species replacement occurs, although species with a high conservation value may be replaced by more common, generalist species, potentially leading to biotic homogenization (Olden 2006).

Species' responses to feeding depend on their functional groups (Mathisen and Skarpe 2011) or on environmental conditions (Moseley et al. 2011). For example, seed-eating bird species responded positively to browsing but negatively 
to feeding stations (Mathisen and Skarpe 2011), whereas the response of insect-eating bird species depended on arthropod prey type (Pedersen et al. 2007, Mathisen et al. 2012). The effects of feeding on rodent abundance were small in an area of high climatic stochasticity (Moseley et al. 2011) and smaller than the inter-annual variation in cyclic populations (Pedersen et al. 2014). Where feeding reduces herbivore winter mortality, scavengers reliant on carcasses could also be affected (sensu Oro et al. 2013).

Feeding stations often attract non-target species such as raccoons (Procyon lotor), collared peccaries (Pecari tajacu), skunks and rodents, particularly where grain or maize (shelled corn) are provided and accessible to these species (Cooper and Ginnett 2000, Moseley et al. 2011, Campbell et al. 2013, Selva et al. 2014). Consequently unnaturally high intra- and inter-specific contact rates can occur around feeding sites (Campbell et al. 2013). Nest predation of, for example, freshwater turtles or ground-nesting birds may increase around feeding stations because of the attraction of nest predators if feeding occurs during the nesting season (Cooper and Ginnett 2000, Hamilton et al. 2002). In addition, issues may arise where provided feed is toxic to non-target species. For example, $20 \%$ of deer corn sold in Texas had levels of aflatoxin that would be toxic to birds and other non-target species (Brown and Cooper 2006). Of 7 controlled studies, 6 showed an impact of feeding on non-target species (Table 2).

Effects on parasite and disease transmission risk.-Naturally occurring diseases and parasites are widespread in wildlife populations and most have minimal overt impacts on populations. However, several key diseases, especially emerging infectious diseases, are widely recognized as threats to conservation, agriculture and public health worldwide (Gortázar et al. 2006, Jones et al. 2008). We expected that feeding ungulates would promote parasite and disease transmission either by increasing direct transmission through interactions such as sneezing, coughing, nose-to-nose contact or sparring (Garner 2001, Miller et al. 2006), or by indirect transmission through infectious materials in the environment (Creech et al. 2012). These include shared feeds contaminated by body fluids from an infectious animal (Palmer et al. 2004). We found strong evidence that feeding can significantly enhance disease transmission, including some diseases that have important impacts on wildlife populations (10/14 studies; Table 2). However, the likelihood of feeding enhancing transmission depends on the lifehistory of pathogens (Vicente et al. 2007; Table 2) and their ability to survive in the environment. For example, enhanced transmission is potentially greater in macroparasites with direct rather than indirect life cycles (Navarro-Gonzalez et al. 2013) and in pathogens that are transmitted during the season when feeding occurs (Cross et al. 2007) or have a very high capacity to survive in the environment for months or years such as prions.

Processes that increase intra- and inter-specific contact rates, for example, by increasing host density or aggregation, have the potential to promote disease transmission (Gortázar et al. 2006, Sorensen et al. 2014). Contact rates of adult female elk were more than twice as high on feeding grounds as elsewhere (Cross et al. 2013); therefore, feed sites may enhance direct and indirect transmission of infectious diseases (e.g., Creech et al. 2012, Campbell et al. 2013). Feeding also increases contact rates with infectious material in the environment such as aborted fetuses on feed grounds where brucellosis (caused by Brucella abortus) is prevalent (Creech et al. 2012) or prions in the case of chronic wasting disease (CWD), which has emerged relatively recently in North America (Miller et al. 2006). Nonetheless, seroprevalence of brucellosis has been increasing with elk density in areas both with and without feed grounds in recent years (Cross et al. 2010). Lateral transmission and the spread of infectious prions in saliva are also important in the transmission of CWD (Salman 2003, Mathiason et al. 2006).

The implementation of feeding programs may affect transmission risks. The quantity of feed provided, number of large feeding sites, provision of fruit and root crops rather than grain, and percentage of sites spreading grain were all associated with increased prevalence of bovine tuberculosis (caused by Mycobacterium bovis) in white-tailed deer (Miller et al. 2003). Density of feeder units was more influential than host abundance in explaining infection by gastrointestinal parasites in wild boar, with feeders appearing to act as points of infection (Navarro-Gonzalez et al. 2013). Clumped, high density feed sites are therefore often associated with higher risks than dispersed feed (Miller et al. 2003). However, spreading feed on the ground may increase the risks of parasite transmission through fecal contamination of feed lines (Hines et al. 2007) and fecal ingestion (Thompson et al. 2008). Moreover, Thompson et al. (2008) found that none of the feeding strategies they evaluated (feed was piled or spread on the ground or provided in troughs, either rationed or ad libitum) reduced the potential risk of disease transmission to levels comparable with natural foraging areas.

Supplemental feeds have been clearly identified as fomites, which can carry disease in the environment and facilitate indirect transmission to new hosts (Palmer et al. 2004, Palmer and Whipple 2006). Key factors influencing the relative effectiveness of disease transmission by this route include the type of feed used, environmental conditions, and the specific disease organism. Agents of diseases such as bovine tuberculosis can survive weeks or months in the environment, whereas prions and endospores of Bacillus anthracis, which cause anthrax, can survive for years or longer (Soparker 1917, Palmer and Whipple 2006). Chronic wasting disease is especially concerning because of its long survival in the environment and on feeds, impacts on ungulate populations, and lack of effective control measures.

Although feeding can increase contact rates, it may potentially reduce the susceptibility of hosts to infection by improving body condition (Gortázar et al. 2006). Relatively few studies have considered this, but we found supporting evidence in $2 / 4$ cases associated with nematode infection (Table 2). In both cases, feeding likely reduced infection by gastrointestinal (Hines et al. 2007) and 
extrapulmonary (Vicente et al. 2007) nematodes because nematodes induce a strong and costly host immune response. In contrast, the transmission of mass-acting directly transmitted infectious diseases such as bovine tuberculosis, which induce only low levels of immunity, is likely to be independent of body condition (Vicente et al. 2007).

\section{DISCUSSION}

Our review shows that whether or not ungulate feeding is effective in achieving its goals, it often results in unintended effects, with the main drivers being sustained high herbivore densities and/or the long-term concentration of individuals around feeding sites. Where enhanced reproduction and increases in herbivore density or aggregation are the intended effects of management, supplementary feeding may be considered effective, although we did not find clear evidence that winter feeding increases autumn carcass mass (Table 1). By contrast, the evidence that diversionary feeding programs are effective is more limited (Table 1). This is primarily because of the difficulties in controlling animal movement, presumably due to other resource needs or disturbance by humans or predators, and because any beneficial diversionary effects are often undermined by increases in population density.

The unintended effects of feeding are generally less well studied (Table 2) so are likely to be more widespread than currently perceived. Many are complex, take time to manifest and act across trophic levels (Timmons et al. 2010, Mathisen et al. 2012), making their full impact difficult to appreciate, especially because of synergistic effects. Where unintended shifts in species composition occur, changes may be considered desirable or undesirable depending on how different species or management outcomes are valued (Minteer and Collins 2005). The genetic, epigenetic, and evolutionary consequences of feeding have barely been considered to date, yet may reveal consequences as marked as those of selective harvesting (Allendorf and Hard 2009, Ciuti et al. 2012) when the required research effort is focused on them. Although the small sample size of studies of some unintended effects preclude drawing conclusions, the balance of currently available evidence across effects suggests that most of the potential unintended effects of feeding do indeed occur (Table 2), particularly under long-term feeding programs. This highlights a genuine cause for concern over the long-term use of feeding programs in many circumstances.

Feeding programs are implemented in a wide variety of ways. Although we found no clear patterns to suggest feed type and distribution methods influenced the overall outcome of feeding, this may partly be due to insufficient research and hence low sample sizes. Nonetheless, to reduce the chances of unintended effects of feeding occurring, population densities should be kept under control, although this may not be easy to achieve. As hunting pressure is increased, animals become more shy and stay within cover; hunting or culling at feeding and bait sites can cause them to use these sites at night or not at all (Tardiff Fleegle and Rosenberry 2010, Ciuti et al. 2012). It may therefore be appropriate to combine population control with range improvement, manipulation of natural forage availability, and positive and negative behavioral reinforcement within an integrated management approach (Mangus 2011, Reimoser and Putman 2011).

\section{Economic Considerations}

Contemporary game harvesting systems have relatively few financial inputs yet can generate considerable income from the sale of hunting opportunities, trophies, or meat where it is legal (Gordon et al. 2004, Olaussen and Skonhoft 2011), as well as indirect revenue associated with selling hunting equipment, guiding services, food, fuel, or accommodation (Smith 2001). Consequently, where supplementary feeding allows larger trophies or more animals to be harvested, it can be profitable despite the costs of feeding, even with expensive high quality feeds (Smith 2001, Peek et al. 2002). Largescale feeding programs are often more cost-effective, whereas considerable financial investment on individual properties may give little return (Putman and Staines 2004, Page and Underwood 2006).

However, high ungulate densities associated with large feeding programs may lead to considerable risks and indirect costs (Smith 2001). These are typically borne by different stakeholders to those receiving the benefits, or by the wider society. Examples are those related to the control of disease (Daszak et al. 2000) or invasive weeds (Pimentel et al. 2005), damage to forestry or crops (Reimoser and Putman 2011), and the infrastructure required to prevent landslides or avalanches in degraded habitats. Ecological costs such as the loss of migration routes or biodiversity impacts are less tangible and particularly difficult to assign monetary values to (Wallace 2007). Both the costs and risks are likely to increase with the scale and duration of feeding, and may be timelagged, whereas benefits occur immediately.

On the other hand, if ungulate feeding is successful in terms of reducing vehicle accidents, it could have important socio-economic benefits to society (Wood and Wolfe 1988, Andreassen et al. 2005) as well as animal welfare (Olaussen and Skonhoft 2011). Although the effectiveness in reducing collisions is not well studied, even limited success might be economically and morally justifiable where high material costs and loss of life occur. Two studies suggested that diversionary feeding may reduce collisions by up to $40 \%$, with benefits exceeding costs in 1 case (Wood and Wolfe 1988). Further research is needed in this area, particular in terms of diverting animals without causing population increases.

\section{Ethical Issues}

Wildlife is heavily affected by anthropogenic activities, particularly climate and land use change, creating ethical obligations for wildlife and conservation managers (Minteer and Collins 2005). Attitudes towards wildlife and these obligations vary over time, regionally and between interest groups, and are reflected in national and international laws. The result is a gradient of management intervention from unmanaged wildlife, through intensively managed wildlife and game ranching, to the extreme of farmed or captive 
wildlife (Orams 2002, Brown and Cooper 2006). Depending on one's perspective, feeding, together with selective harvesting, fencing, and predator control, may be viewed as either an obligation of hunters in their role as guardians of wildlife, or as steps towards the domestication of ungulates (Brown and Cooper 2006, Mysterud 2010, Schmidt 2014). Feeding comes at the price of taming wildlife, giving rise to public concerns (Butler et al. 2005). It can be perceived to devalue wildlife and wildlife habitats (Smith 2001) and contravene the concepts of fair chase and public ownership of wildlife (Brown and Cooper 2006, Inslerman et al. 2006). By shifting wildlife management towards agricultural production, feeding affects hunters' and the public's perceptions of wildlife and the acceptability of natural mortality (Schmidt 2014). Most stakeholders would likely consider the extreme situation in which large game animals only occur in fed populations to be undesirable, but ultimately it is up to society to decide the acceptable extent of intervention.

\section{MANAGEMENT IMPLICATIONS}

To feed or not to feed? This is the question that we urge managers to consider fully before implementing feeding programs. Our evidence indicates that unintended effects of feeding are likely when practiced over the long-term, in ways that allow locally high densities of ungulates to occur and when the feed provided does not match that of the foraging strategy of the target species (Table 2). Therefore managers should consider the following points:

1. To reduce the potential for unintended effects, population densities should be kept below some pre-determined threshold; for example, the natural carrying capacity of the area before feeding. In addition, sufficient natural forage should be available in seasonal ranges occupied outside the feeding season. Population control, ideally carried out during a short and intense hunting season that ends before feeding starts, is also likely to improve the effectiveness of diversionary feeding.

2. A low density feeding approach may reduce disease spread and is likely better for the surrounding vegetation, although contact rates still tend to be higher than in natural situations (Thompson et al. 2008) and dispersed feeds can also carry infectious organisms. Widely dispersed feed reduces monopolization by a few individuals, improving access by subdominants and reducing stress and aggression.

3. The feed provided needs to be appropriate to the target species. Natural forage is likely the best option (although this may require further testing; Månsson et al. 2010) to limit the attraction of non-target species and dietary changes that indirectly lead to undesired effects. Because the management of invasive species can be extremely costly (Pimentel et al. 2005), the use of certified weed-free forage (North American Invasive Species Management Association 2013) is recommended, particularly in or near protected areas.
4. Feeding sites should be established in areas away from vulnerable vegetation and disturbance, and where multiple habitat requirements can be met.

5. Long-term monitoring should be implemented to ensure early detection of unintended effects of feeding such as disease (Sorensen et al. 2014), establishment of invasive species, and habitat impacts. Defensible baselines should also be established prior to implementing feeding.

6. At the outset, stakeholders should agree who will pay the direct costs of maintaining the feeding program over time and who will pay the costs of unintended effects. Furthermore, the longevity of a feeding program should be considered as the severity of unintended effects may increase over time (e.g., van Beest et al. 2010a). The consequences of stopping feeding and the reversibility of unintended effects are as yet largely unknown (but see Groot Bruinderink et al. 2000, Mangus 2011) and will likely require a dramatic reduction in population size to a level that can be supported by the existing natural habitat.

\section{ACKNOWLEDGMENTS}

Funding was provided by Oslo municipality and the County Governors of Hedmark, Akershusand Telemark, Norway, and University of Saskatchewan, Canada. We thank E. Merrill and an anonymous reviewer for their constructive comments.

\section{LITERATURE CITED}

Allendorf, F. W., and J. J. Hard. 2009. Human-induced evolution caused by unnatural selection through harvest of wild animals. Proceedings of the National Academy of Sciences, USA 106:9987-9994.

Anderson, E. M. 2007. Changes in bird communities and willow habitats associated with fed elk. Wilson Journal of Ornithology 119:400-409.

Andreassen, H. P., H. Gundersen, and T. Storaas. 2005. The effect of scentmarking, forest clearing, and supplemental feeding on moose-train collisions. Journal of Wildlife Management 69:1125-1132.

Andrew, M. H. 1988. Grazing impact in relation to livestock watering points. Trends in Ecology and Evolution 3:336-339.

Austin, Z., J. C. R. Smart, S. Yearley, R. J. Irvine, and P. C. L. White. 2010. Identifying conflicts and opportunities for collaboration in the management of a wildlife resource: a mixed-methods approach. Wildlife Research 37:647-657.

Ballesteros, M., B.-J. Bårdsen, P. Fauchald, K. Langeland, A. Stien, and T. Tveraa. 2013. Combined effects of long-term feeding, population density and vegetation green-up on reindeer demography. Ecosphere 4:45.

Bårdsen, B.-J., P. Fauchald, T. Tveraa, K. Langeland, and M. Nieminen. 2009. Experimental evidence of cost of lactation in a low risk environment for a long-lived mammal. Oikos 118:837-852.

Bårdsen, B.-J., P. Fauchald, T. Tveraa, K. Langeland, N. G. Yoccoz, and R. A. Ims. 2008. Experimental evidence of a risk-sensitive reproductive allocation in a long-lived mammal. Ecology 89:829-837.

Barnett, D. T., and T. J. Stohlgren. 2001. Aspen persistence near the National Elk Refuge and Gros Ventre Valley elk feedgrounds of yoming, USA. Landscape Ecology 16:569-580.

Bartoskewitz, M. L., D. G. Hewitt, J. S. Pitts, and F. C. Bryant. 2003. Supplemental feed use by free-ranging white-tailed deer in southern Texas. Wildlife Society Bulletin 31:1218-1228.

Bartuszevige, A. M., and B. A. Endress. 2008. Do ungulates facilitate native and exotic plant spread? Seed dispersal by cattle, elk and deer in northeastern Oregon. Journal of Arid Environments 72:904-913.

Bayliss, P., and D. Choquenot. 2002. The numerical response: rate of increase and food limitation in herbivores and predators. Philosophical Transactions of the Royal, Society of London Series B 357:1233-1248. 
Bieber, C., and T. Ruf. 2005. Population dynamics in wild boar Sus scrofa: ecology, elasticity of growth rate and implications for the management of pulsed resource consumers. Journal of Applied Ecology 42:1203-1213.

Blanchong, J. A., K. T. Scribner, B. K. Epperson, and S. R. Winterstein. 2006. Changes in artificial feeding regulations impact white-tailed deer fine-scale spatial genetic structure. Journal of Wildlife Management 70:1037-1043.

Boyce, M. S. 1989. The Jackson Elk Herd: intensive wildlife management in North America. Cambridge University Press, Cambridge, United Kingdom.

Brown, E., and J. Mandery. 1962. Planting and fertilisation as a possible means of controlling distribution of big game animals. Journal of Forestry 60:33-35.

Brown, R. D., and S. M. Cooper. 2006. The nutritional, ecological, and ethical arguments against baiting and feeding white-tailed deer. Wildlife Society Bulletin 34:519-524.

Butler, M. J., A. P. Teaschner, W. B. Ballard, and B. K. McGee. 2005. Commentary: wildlife ranching in North America-arguments, issues, and perspectives. Wildlife Society Bulletin 33:381-389.

Calenge, C., D. Maillard, P. Fournier, and C. Fouque. 2004. Efficiency of spreading maize in the garrigues to reduce wild boar (Sus scrofa) damage to Mediterranean vineyards. European Journal of Wildlife Research 50: 112-120.

Campbell, T. A., D. B. Long, and S. A. Shriner. 2013. Wildlife contact rates at artificial feeding sites in Texas. Environmental Management 51: 1187-1193.

Cash, S. D., D. L. Zamora, and A. W. Lenssen. 1998. Viability of weed seeds in feed pellet processing. Journal of Range Management 51: 181-185.

Ciuti, S., T. B. Muhly, D. G. Paton, A. D. McDevitt, M. Musiani, and M. S. Boyce. 2012. Human selection of elk behavioural traits in a landscape of fear. Proceedings of the Royal Society B-Biological Sciences 279:4407-4416.

Cook, R. C., J. G. Cook, D. J. Vales, B. K. Johnson, S. M. McCorquodale, L. A. Shipley, R. A. Riggs, L. L. Irwin, S. L. Murphie, B. L. Murphie, K. A. Schoenecker, F. Geyer, P. B. Hall, R. D. Spencer, D. A. Immell, D. H. Jackson, B. L. Tiller, P. J. Miller, and L. Schmitz. 2013. Regional and seasonal patterns of nutritional condition and reproduction in elk. Wildlife Monographs 184.

Cooper, S. M., and T. F. Ginnett. 2000. Potential effects of supplemental feeding of deer on nest predation. Wildlife Society Bulletin 28: 660-666.

Cooper, S. M., M. K. Owens, R. M. Cooper, and T. F. Ginnett. 2006. Effect of supplemental feeding on spatial distribution and browse utilization by white-tailed deer in semi-arid rangeland. Journal of Arid Environments 66:716-726.

Côté, S. D., T. P. Rooney, J.-P. Tremblay, C. Dussault, and D. M. Waller. 2004. Ecological impacts of deer overabundance. Annual Review of Ecology and Systematics 35:113-147.

Creech, T. G., P. C. Cross, B. M. Scurlock, E. J. Maichak, J. D. Rogerson, J. C. Henningsen, and S. Creel. 2012. Effects of low-density feeding on elk-fetus contact rates on Wyoming feedgrounds. Journal of Wildlife Management 76:877-886.

Cross, P. C., T. G. Creech, M. R. Ebinger, K. Manlove, K. Irvine, J. Henningsen, J. Rogerson, B. M. Scurlock, and S. Creel. 2013. Female elk contacts are neither frequency nor density dependent. Ecology 94: 2076-2086.

Cross, P. C., W. H. Edwards, B. M. Scurlock, E. J. Maichak, and J. D. Rogerson. 2007. Effects of management and climate on elk brucellosis in the Greater Yellowstone ecosystem. Ecological Applications 17: 957-964.

Cross, P. C., D. M. Heisey, B. M. Scurlock, W. H. Edwards, M. R. Ebinger, and A. Brennan. 2010. Mapping brucellosis increases relative to elk density using hierarchical Bayesian models. PLoS ONE 5:e10322.

Daszak, P., A. A. Cunningham, and A. D. Hyatt. 2000. Emerging infectious diseases of wildlife - threats to biodiversity and human health. Science 287:443-449.

Doenier, P. B., G. D. DelGiudice, and M. R. Riggs. 1997. Effects of winter supplemental feeding on browse consumption by white-tailed deer. Wildlife Society Bulletin 25:235-243.

Donohue, R. N., D. G. Hewitt, T. E. Fulbright, C. A. DeYoung, A. R. Litt, and D. A. Draeger. 2013. Aggressive behavior of white-tailed deer at concentrated food sites as affected by population density. Journal of Wildlife Management 77:1401-1408.

Dunkley, L., and M. R. L. Cattet. 2003. A comprehensive review of the ecological and human social effects of artificial feeding and baiting of wildlife. Canadian Cooperative Wildlife Health Centre, Saskatoon, Saskatchewan, Canada.

Fauchald, P., T. Tveraa, C. Henaug, and N. G. Yoccoz. 2004. Adaptive regulation of body reserves in reindeer, Rangifer tarandus: a feeding experiment. Oikos 107:583-591.

Forristal, V. E., S. Creel, M. L. Taper, B. M. Scurlock, and P. C. Cross. 2012. Effects of supplemental feeding and aggregation on fecal glucocorticoid metabolite concentrations in elk. Journal of Wildlife Management 76:694-702.

Foster, C. N., P. S. Barton, and D. B. Lindenmayer. 2014. Effects of large herbivores on other animals. Journal of Applied Ecology 51:929-938.

Fuller, R. J., and R. M. A. Gill. 2001. Ecological impacts of increasing numbers of deer in British woodland. Forestry 74:193-199.

Garner, M. S. 2001. Movement patterns and behavior at winter-feeding and fall baiting stations in a population of white-tailed deer infected with bovine tuberculosis in the northeastern Lower Peninsula of Michigan. Dissertation, Michigan State University, East Lansing, USA.

Gordon, I. J., A. J. Hester, and M. Festa-Bianchet. 2004. The management of wild large herbivores to meet economic, conservation and environmental objectives. Journal of Applied Ecology 41:1021-1031.

Gortázar, C., P. Acevedo, F. Ruiz-Fons, and J. Vicente. 2006. Disease risks and overabundance of game species. European Journal of Wildlife Research 52:81-87.

Groot Bruinderink, G. W. T. A., and E. Hazebroek. 1996. Ungulate traffic collisions in Europe. Conservation Biology 10:1059-1067.

Groot Bruinderink, G. W. T. A., D. R. Lammertsma, and E. Hazebroek. 2000. Effects of cessation of supplemental feeding on mineral status of red deer Cervus elaphus and wild boar Sus scrofa in the Netherlands. Acta Theriologica 45:71-85.

Gundersen, H., H. P. Andreassen, and T. Storaas. 2004. Supplemental feeding of migratory moose Alces alces: forest damage at two spatial scales. Wildlife Biology 10:213-223.

Hamilton, A. M., A. H. Freedman, and R. Franz. 2002. Effects of deer feeders, habitat and sensory cues on predation rates on artificial turtle nests. American Midland Naturalist 147:123-134.

Hines, A. M., V. O. Ezenwa, P. Cross, and J. D. Rogerson. 2007. Effects of supplemental feeding on gastrointestinal parasite infection in elk (Cervus elaphus): preliminary observations. Veterinary Parasitology 148:350-355.

Huijser, M. P., J. W. Duffield, A. P. Clevenger, R. J. Ament, and P. T. McGowan. 2009. Cost-benefit analyses of mitigation measures aimed at reducing collisions with large ungulates in the United States and Canada: a decision support tool. Ecology and Society 14:15.

Imesch-Bebié, N., H. Gander, and R. Schnidrig-Petrig. 2010. Ungulates and their management in Switzerland. Pages 357-391 in M., Apollonio, R., Andersen and R. J., Putman, editors. European ungulates and their management in the 21st century. Cambridge University Press, Cambridge United Kingdom.

Inslerman, R. A., J. E. Miller, D. L. Baker, R. Cumberland, P. Doerr, J. E. Kennamer, E. R. Stinson, and S. J. Williamson. 2006. Baiting and supplemental feeding of game wildlife species. The Wildlife Society Technical Review 06-1, Bethesda, Maryland, USA.

Jacobsen, E., K. Hove, R. S. Bjarghov, and S. Skjenneberg. 1981. Supplementary feeding of female reindeer on a lichen diet during the last part of pregancy. Effects on plasma composition, milk production and calf growth. Acta Agriculturae Scandinavica 31:81-86.

Jaroszewicz, B., E. Pirozikow, and R. Sagehorn. 2009. Endozoochory by European bison (Bison bonasus) in Bialowieza Primeval Forest across a management gradient. Forest Ecology and Management 258:11-17.

Johnsen, K. 2012. Moose (Alces alces) and red deer (Cervus elaphus) at winter feeding stations: interspecific avoidance in space and time? Thesis, Hedmark University College, Koppang, Norway.

Jones, K. E., N. G. Patel, M. A. Levy, A. Storeygard, D. Balk, J. L. Gittleman, and P. Daszak. 2008. Global trends in emerging infectious diseases. Nature 451:990-994.

Kilpatrick, H. J., A. M. LaBonte, and J. S. Barclay. 2010. Use of bait to increase archery deer harvest in an urban-suburban landscape. Journal of Wildlife Management 74:714-718. 
Kowalczyk, R., P. Taberlet, E. Coissac, A. Valentini, C. Miquel, T. Kamiński, and J. M. Wójcik. 2011. Influence of management practices on large herbivore diet-case of European bison in Białowieża Primeval Forest (Poland). Forest Ecology and Management 261:821-828.

Kozak, H. M., R. J. Hudson, and L. A. Renecker. 1994. Supplemental winter feeding. Rangelands 16:153-156.

Lewis, J. 1973. Longevity of crop and weed seeds: survival after 20 years in soil. Weed Research 13:179-191.

Lewis, T. L., and O. J. Rongstad. 1998. Effects of supplemental feeding on white-tailed deer, Odocoileus virginianus, migration and survival in Northern Wisconsin. Canadian Field-Naturalist 112:75-81.

Lubow, B. C., and B. L. Smith. 2004. Population dynamics of the Jackson elk herd. Journal of Wildlife Management 68:810-829.

MacDougall, A. S., and R. Turkington. 2005. Are invasive species the drivers or passengers of change in degraded ecosystems? Ecology 86: 42-55.

Mangus, D. L. 2011. Reducing reliance on supplemental winter feeding in elk (Cervus canadensis): an applied management experiment at Deseret Land and Livestock Ranch, Utah. Thesis, Utah State University, Logan, USA.

Månsson, J., R. Bergström, A. Pehrson, M. Skoglund, and C. Skarpe. 2010. Felled Scots pine (Pinus sylvestris) as supplemental forage for moose (Alces alces): browse availability and utilization. Scandinavian Journal of Forest Research 25:21-31.

Martínez-Abraín, A., and D. Oro. 2013. Preventing the development of dogmatic approaches in conservation biology: a review. Biological Conservation 159:539-547.

Mathiason, C. K., J. G. Powers, S. J. Dahmes, D. A. Osborn, K. V. Miller, R. J. Warren, G. L. Mason, S. A. Hays, J. Hayes-Klug, D. M. Seelig, M. A. Wild, L. L. Wolfe, T. R. Spraker, M. W. Miller, C. J. Sigurdson, G. C. Telling, and E. A. Hoover. 2006. Infectious prions in the saliva and blood of deer with chronic wasting disease. Science 314:133-136.

Mathisen, K. M., F. Buhtz, K. Danell, R. Bergström, C. Skarpe, O. Suominen, and I. L. Persson. 2010. Moose density and habitat productivity affects reproduction, growth and species composition in field layer vegetation. Journal of Vegetation Science 21:705-716.

Mathisen, K. M., J. M. Milner, F. M. van Beest, and C. Skarpe. 2014. Longterm effects of supplementary feeding of moose on browsing impact at a landscape scale. Forest Ecology and Management 314:104-111.

Mathisen, K. M., S. Pedersen, E. B. Nilsen, and C. Skarpe. 2012. Contrasting responses of two passerine bird species to moose browsing. European Journal of Wildlife Research 58:535-547.

Mathisen, K. M., and C. Skarpe. 2011. Cascading effects of moose (Alces alces) management on birds. Ecological Research 26:563-574.

Merrill, E., H. Sand, B. Zimmermann, H. McPhee, N. Webb, M. Hebblewhite, P. Wabakken, and J. L. Frair. 2010. Building a mechanistic understanding of predation with GPS-based movement data. Philosophical Transactions of the Royal Society B: Biological Sciences 365: 2279-2288.

Miller, M. W., N. T. Hobbs, and S. J. Tavener. 2006. Dynamics of prion disease transmission in mule deer. Ecological Applications 16: 2208-2214.

Miller, R., J. B. Kaneene, S. D. Fitzgerald, and S. M. Schmitt. 2003. Evaluation of the influence of supplemental feeding of white-tailed deer (Odocoileus virginianus) on the prevalence of bovine tuberculosis in the Michigan wild deer population. Journal of Wildlife Diseases 39: 84-95.

Milner, J. M., F. M. van Beest, E. J. Solberg, and T. Storaas. 2013. Reproductive success and failure-the role of winter body mass in reproductive allocation in Norwegian moose. Oecologia 172:995-1005.

Minteer, B. A., and J. P. Collins. 2005. Ecological ethics: building a new tool kit for ecologists and biodiversity managers. Conservation Biology 19:1803-1812.

Moseley, W. A., S. M. Cooper, D. G. Hewitt, T. E. Fulbright, and C. A. Deyoung. 2011. Effects of supplemental feeding and density of white-tailed deer on rodents. Journal of Wildlife Management 75: 675-681.

Murden, S. B., and K. L. Risenhoover. 1993. Effects of habitat enrichment on patterns of diet selection. Ecological Applications 3:497-505.

Mysterud, A. 1999. Seasonal migration pattern and home range of roe deer (Capreolus capreolus) in an altitudinal gradient in Southern Norway. Journal of Zoology 247:479-486.
Mysterud, A. 2010. Still walking on the wild side? Management actions as steps towards 'semi-domestication' of hunted ungulates. Journal of Applied Ecology 47:920-925.

Mysterud, A. 2011. Selective harvesting of large mammals: how often does it result in directional selection? Journal of Applied Ecology 48:827-834.

North American Invasive Species Management Association. 2013. Weed Free Forage. < www.naisma.org/weed-free-forage > . Accessed 19 Nov 2013.

Navarro-Gonzalez, N., P. Fernández-Llario, J. E. Pérez-Martín, G. Mentaberre, J. M. López-Martín, S. Lavín, and E. Serrano. 2013. Supplemental feeding drives endoparasite infection in wild boar in Western Spain. Veterinary Parasitology 196:114-123.

Olaussen, J. O., and A. Skonhoft. 2011. A cost-benefit analysis of moose harvesting in Scandinavia. A stage structured modelling approach. Resource and Energy Economics 33:589-611.

Olden, J. D. 2006. Biotic homogenization: a new research agenda for conservation biogeography. Journal of Biogeography 33:2027-2039.

Olguin, C. A., T. Landete-Castillejos, F. Ceacero, A. J. García, and L. Gallego. 2013. Effects of feed supplementation on mineral composition, mechanical properties and structure in femurs of Iberian red deer hinds (Cervus elaphus hispanicus). PLoS ONE 8:e65461.

Orams, M. B. 2002. Feeding wildlife as a tourism attraction: a review of issues and impacts. Tourism Management 23:281-293.

Oro, D., M. Genovart, G. Tavecchia, M. S. Fowler, and A. MartínezAbraín. 2013. Ecological and evolutionary implications of food subsidies from humans. Ecology Letters 16:1501-1514.

Ozoga, J. J., and L. J. Verme. 1982. Physical and reproductive characteristics of a supplementally-fed white-tailed deer herd. Journal of Wildlife Management 46:281-301.

Page, B. D., and H. B. Underwood. 2006. Comparing protein and energy status of winter-fed white-tailed deer. Wildlife Society Bulletin 34:716-724.

Palmer, M. V., W. R. Waters, and D. L. Whipple. 2004. Shared feed as a means of deer-to-deer transmission of Mycobacterium bovis. Journal of Wildlife Diseases 40:87-91.

Palmer, M. V., and D. L. Whipple. 2006. Survival of Mycobacterium bovis on feedstuffs commonly used as supplemental feed for white-tailed deer (Odocoileus virginianus). Journal of Wildlife Diseases 42:853-858.

Parker, K. L., P. S. Barboza, and M. P. Gillingham. 2009. Nutrition integrates environmental responses of ungulates. Functional Ecology 23:57-69.

Pedersen, S., K. M. Mathisen, L. Gorini, H. P. Andreassen, E. Røskaft, and C. Skarpe. 2014. Small mammal responses to moose supplemental winter feeding. European Journal of Wildlife Research 60:527-534.

Pedersen, S., E. B. Nilsen, and H. P. Andreassen. 2007. Moose winter browsing affects the breeding success of great tits. Ecoscience 14:499-506.

Peek, J. M., K. T. Schmidt, M. J. Dorrance, and B. L. Smith. 2002. Supplemental feeding and farming of elk. Pages 614-647 in D. E., Toweill and P. N., Thomas, editors. Elk of North America: ecology and management. Smithsonian Institute Press, Washington, DC, USA.

Pérez-González, J., A. M. Barbosa, J. Carranza, and J. Torres-Porras. 2010. Relative effect of food supplementation and natural resources on female red deer distribution in a Mediterranean ecosystem. Journal of Wildlife Management 74:1701-1708.

Peterson, C., and T. A. Messmer. 2007. Effects of winter-feeding on mule deer in northern Utah. Journal of Wildlife Management 71:1440-1445.

Peterson, C., and T. A. Messmer. 2011. Biological consequences of winterfeeding of mule deer in developed landscapes in northern Utah. Wildlife Society Bulletin 35:252-260.

Picard, M., and C. Baltzinger. 2012. Hitch-hiking in the wild: should seeds rely on ungulates? Plant Ecology and Evolution 145:24-30.

Pimentel, D., R. Zuniga, and D. Morrison. 2005. Update on the environmental and economic costs associated with alien-invasive species in the United States. Ecological Economics 52:273-288.

Putman, R., J. Langbein, P. Green, and P. Watson. 2011. Identifying threshold densities for wild deer in the UK above which negative impacts may occur. Mammal Review 41:175-196.

Putman, R. J., and B. W. Staines. 2004. Supplementary winter feeding of wild red deer Cervus elaphus in Europe and North America: justifications, feeding practice and effectiveness. Mammal Review 34:285-306.

Rajský, M., M. Vodňanský, P. Hell, J. Slamečka, R. Kropil, and D. Rajský. 2008. Influence supplementary feeding on bark browsing by red deer (Cervus elaphus) under experimental conditions. European Journal of Wildlife Research 54:701-708. 
Reimoser, F., and R. Putman. 2011. Impacts of wild ungulates on vegetation: costs and benefits. Pages 144-191 in R. J., Putman, M., Apollonio and R., Andersen, editors. Ungulate management in Europe: problems and practices. Cambridge University Press, Cambridge, United Kingdom.

Rinella, M. J., R. Dean, M. Vavra, and C. G. Parks. 2012. Vegetation responses to supplemental winter feeding of elk in western Wyoming. Western North American Naturalist 72:78-83.

Rodriguez-Hidalgo, P., C. Gortazar, F. S. Tortosa, C. Rodriguez-Vigal, Y. Fierro, and J. Vicente. 2010. Effects of density, climate, and supplementary forage on body mass and pregnancy rates of female red deer in Spain. Oecologia 164:389-398.

Rudolph, B. A., S. J. Riley, G. J. Hickling, B. J. Frawley, M. S. Garner, and S. R. Winterstein. 2006. Regulating hunter baiting for white-tailed deer in Michigan: biological and social considerations. Wildlife Society Bulletin 34:314-321.

Sahlsten, J., N. Bunnefeld, J. Månsson, G. Ericsson, R. Bergström, and H. Dettki. 2010. Can supplementary feeding be used to redistribute moose? Wildlife Biology 16:85-92.

Salman, M. D. 2003. Chronic wasting disease in deer and elk: scientific facts and findings. Journal of Veterinary Medical Science 65: 761-768.

Sánchez-Prieto, C. B., J. Carranza, and F. J. Pulido. 2004. Reproductive behavior in female Iberian red deer: effects of aggregation and dispersion of food. Journal of Mammalogy 85:761-767.

Schmidt, K. 1993. Winter ecology of nonmigratory Alpine red deer. Oecologia 95:226-233.

Schmidt, K. T. 2014. The way supplemental feeding changes our attitude towards red deer and natural mortality. Pages 269-278 in K., Baker, R., Carden and R., Madgwick, editors. Deer and people. Windgather Press, Oxford, United Kingdom.

Schmidt, K., L. J. Seivwright, H. Hoi, and B. W. Staines. 1998. The effect of depletion and predictability of distinct food patches on the timing of aggression in red deer stags. Ecography 21:415-422.

Schmidt, K. T., and H. Hoi. 1999. Feeding tactics of low-ranking red deer stags at supplementary feeding sites. Ethology 105:349-360.

Schmidt, K. T., and H. Hoi. 2002. Supplemental feeding reduces natural selection in juvenile red deer. Ecography 25:265-272.

Schmitz, O. J. 1990. Management implications of foraging theoryevaluating deer supplemental feeding. Journal of Wildlife Management 54:522-532.

Selva, N., T. Berezowska-Cnota, and I. Elguero-Claramunt. 2014. Unforeseen effects of supplementary feeding: ungulate baiting sites as hotspots for ground-nest predation. PLoS ONE 9:e90740.

Smith, B. L. 2001. Winter feeding of elk in western North America. Journal of Wildlife Management 65:173-190.

Smith, B. L., and S. H. Anderson. 1998. Juvenile survival and population regulation of the Jackson elk herd. Journal of Wildlife Management 62:1036-1045.

Smith, B. L., E. C. Cole, and D. S. Dobkin. 2004. Imperfect pasture. A century of change at the National Elk, Refuge in Jackson Hole, Wyoming. Grand Teton Natural History Association, Moose, Wyoming, USA.

Smith, B. L., R. L. Robbins, and S. H. Anderson. 1997. Early development of supplementally fed, free-ranging elk. Journal of Wildlife Management 61:26-38.

Soparker, M. B. 1917. The vitality of the tubercle bacillus outside the body. Indian Journal of Medical Research 4:627-650.

Sorensen, A., F. M. van Beest, and R. K. Brook. 2014. Impacts of wildlife baiting and supplemental feeding on infectious disease transmission risk: a synthesis of knowledge. Preventive Veterinary Medicine 113:356-363.
Tardiff Fleegle, J., and C. Rosenberry. 2010. Effect of bait on deer harvests in Special Regulation Areas of Pennsylvania. Final report for Project 06210, Job 21014. Pennsylvania Game Commission, Harrisburg, Pennsylvania, USA.

Tarr, M. D., and P. J. Pekins. 2002. Influences of winter supplemental feeding on the energy balance of white-tailed deer fawns in New Hampshire, U.S.A. Canadian Journal of Zoology 80:6-15.

Thompson, A. K., M. D. Samuel, and T. R. Van Deelen. 2008. Alternative feeding strategies and potential disease transmission in Wisconsin white-tailed deer. Journal of Wildlife Management 72: 416-421.

Timmons, G. R., D. G. Hewitt, C. A. DeYoung, T. E. Fulbright, and D. A. Draeger. 2010. Does supplemental feed increase selective foraging in a browsing ungulate? Journal of Wildlife Management 74:995-1002.

van Beest, F. M., H. Gundersen, K. M. Mathisen, J. M. Milner, and C. Skarpe. 2010a. Long-term browsing impact around diversionary feeding stations for moose in Southern Norway. Forest Ecology and Management 259:1900-1911.

van Beest, F. M., L. E. Loe, A. Mysterud, and J. M. Milner. $2010 b$. Comparative space use and habitat selection of moose around feeding stations. Journal of Wildlife Management 74:219-227.

van Beest, F. M., and J. M. Milner. 2013. Behavioural responses to thermal conditions affect seasonal mass change in a heat-sensitive northern ungulate. PLoS ONE 8:e65972.

van Deelen, T. R., B. Dhuey, K. R. McCaffery, and R. E. Rolley. 2006. Relative effects of baiting and supplemental antlerless seasons on Wisconsin's 2003 deer harvest. Wildlife Society Bulletin 34:322328

Veiberg, V., L. E. Loe, A. Mysterud, R. Langvatn, and N. C. Stenseth. 2004. Social rank, feeding and winter weight loss in red deer: any evidence of interference competition? Oecologia 138:135-142.

Vicente, J., U. Höfle, I. G. Fernández-De-Mera, and C. Gortazar. 2007. The importance of parasite life history and host density in predicting the impact of infections in red deer. Oecologia 152:655-664.

Wallace, K. J. 2007. Classification of ecosystem services: problems and solutions. Biological Conservation 139:235-246.

Wallander, R. T., B. E. Olson, and J. R. Lacey. 1995. Spotted knapweed seed viability after passing through sheep and mule deer. Journal of Range Management 48:145-149.

Webb, S. L., D. G. Hewitt, D. D. Marquardt, and M. W. Hellickson. 2008. Spatial distributions of adult male white-tailed deer relative to supplemental feed sites. Texas Journal of Agriculture and Natural Resources 21:32-42.

White, P. J., K. M. Proffitt, L. D. Mech, S. B. Evans, J. A. Cunningham, and K. L. Hamlin. 2010. Migration of northern Yellowstone elk: implications of spatial structuring. Journal of Mammalogy 91:827-837.

Winterstein, S. 1992. Michigan hunter opinion surveys. Federal Aid in Wildlife Restoration Report W-127-R. Michigan Department of Natural Resources, Wildlife Division, Lansing, Michigan, USA.

Wood, P., and M. L. Wolfe. 1988. Intercept feeding as a means of reducing deer-vehicle collisions. Wildlife Society Bulletin 16:376-380.

Associate Editor: David Euler.

\section{SUPPORTING INFORMATION}

Additional supporting information may be found in the online version of this article at the publisher's web-site. 